\title{
Cell Cycle Blockers Mimosine, Ciclopirox, and Deferoxamine Prevent the Death of PC12 Cells and Postmitotic Sympathetic Neurons after Removal of Trophic Support
}

\author{
Stephen E. Farinelli and Lloyd A. Greene \\ Department of Pathology and Center for Neurobiology and Behavior, Columbia University College of Physicians and \\ Surgeons, New York, New York 10032
}

In the present study, we tested whether apoptotic neuronal death caused by withdrawal of trophic support might be prevented by agents that block cell cycle progression. We used three complementary model systems that exhibit apoptotic death: dividing PC12 cells deprived of serum; nondividing, neuronally differentiated PC12 cells deprived of nerve growth factor (NGF); and primary cultures of postmitotic sympathetic neurons deprived of NGF. We show that cell death in each case can be suppressed by treatment with the G1/S blockers mimosine, ciclopirox, and deferoxamine at concentrations that correlate with their abilities to block PC12 cell proliferation. In contrast, agents that block cell cycle progression in the S-, G2-, or M-phase do not prevent cell death. These observations support the hypothesis that removal of trophic support from dividing or postmitotic neuronal cells provokes their apoptotic death by causing them either to proceed through or to attempt to re-enter an uncoordinated and consequently fatal cell cycle. Moreover, the data suggest that simply blocking the cycle at any point is not protective but, rather, that it is necessary to block at specific "safe" points. This study defines a safe point in the cell cycle before the G1/S transition that is demarcated by the action of these three agents.

Key words: mimosine; deferoxamine; ciclopirox; NGF; apoptosis; sympathetic neurons, PC12 cells; programmed cell death
The mechanisms by which nerve growth factor (NGF) and other neurotrophic agents promote neuronal survival are currently unresolved. Cultured sympathetic neurons deprived of NGF undergo apoptotic death (Edwards ct al., 1991; Batistatou and Greene, 1993; Deckwerth and Johnson, 1993; Edwards and Tolkovsky, 1994) and have been valuable for investigating mechanisms of survival and death (Deckwerth and Johnson, 1993; Edwards and Tolkovsky, 1994; Greenlund et al., 1995).

The PC12 rat pheochromocytoma cell line (Greene and Tischler, 1976) also has been used as a model to study the mechanism of apoptotic neuronal death after withdrawal of trophic support. In serum-containing medium, PC12 cells divide and display many characteristics of adrenal chromaffin cells. Within several days of NGF exposure, these cells stop dividing and acquire numerous properties of mature sympathetic neurons (for review, see Greene and Tischler, 1982; Guroff, 1985). When cultured in serum-free medium without NGF, both naive and neuronally differentiated (NGF-pretreated) $\mathrm{PCl} 2$ cells die via an apoptotic mechanism (Greene, 1978; Batistatou and Greene, 1991). The addition of NGF to the cells in serum-free medium rescues them from death. Because both naive proliferating and neuronally differentiated nonproliferating PC12 cells are sustained by NGF under serum-free conditions, the line may be used to model the survival mechanisms of both neuroblasts and postmitotic neurons.

Received Aug. 2, 1995; revised Nov. 1, 1995; accepted Nov. 7,1995

This research was supported in part by grants from NIH-NINDS and the March of Dimes Birth Defects Foundation. S.E.F. was supported in part by postdoctoral training grants from the National Institute of Aging (5 T32 AG(0)189) and the National Cancer Institute (5 T32 CA09503). We thank Drs. G. Ferrari and C. Troy for helpful discussion.

Correspondence should be addressed to Lloyd A. Greenc, Department of Pathology and Center for Neurobiology and Behavior, Columbia University College of Physicians and Surgeons, $630 \mathrm{~W}$. 168 th Street, New York, NY 10032.

Copyright 1996 Society for Neuroscience $0270-6474 / 96 / 161150-13 \$ 05.00 / 0$
Studies with neuronally differentiated PC12 cells reveal that, as with sympathetic neurons (Martin et al., 1988), death caused by withdrawal of trophic support is retarded by RNA and protein synthesis inhibitors (Mesner et al., 1992; Pittman et al., 1993). In contrast, such inhibitors do not prevent the death of naive PC12 cells (Rukenstein et al., 1991). We suggest that this difference in behavior illuminates the underlying role of NGF and other trophic agents in promoting cell survival. For dividing neuroblast-like naive PC12 cells, we hypothesize that trophic factors such as NGF are required for successful cell cycle traverse and that in the absence of such support, an abortive and fatal cycle occurs (Batistatou and Greene, 1993; Ferrari and Greene, 1994; Greene et al., 1995a,b). This proposal is supported by a number of recent findings with non-neuronal cells (Yonish-Rouach et al., 1991, 1993; Colombel et al., 1992; Evan et al., 1992; Shi et al., 1994). In the case of neuroblasts, cell cycle molecules are constitutively expressed; hence, attempted replication and death are independent of synthesis. In contrast, for nondividing neurons and NGFpretreated PC12 cells, we propose that RNA and protein synthesis blockers prevent neuronal death because they suppress the production of proteins required for attempted cycle re-entry (Ferrari and Greene, 1994; Greene et al., 1995a,b). In consonance with this, long-term NGF exposure exerts antimitogenic actions on PC12 (Greene and Tischler, 1976; Ferrari and Greene, 1994) and chromaffin cells (Tischler et al., 1993). Also, Freeman et al. (1994) reported that the $\mathrm{G} 1$ cyclin D1 is induced during the death of NGF-deprived sympathetic neurons, and Brooks et al. (1993) observed that withdrawal of NGF from neuronally differentiated $\mathrm{PC} 12$ cells triggers the reappearance of $\mathrm{M}$-phase-associated cdc2 activity.

We reported recently that the suppression of proliferative capacity in both naive and neuronally differentiated PC12 cells by overexpression of dominant-negative ras or by treatment 
with $N$-acetylcystcinc protects them from removal of trophic support (Ferrari and Grecne, 1994; Ferrari et al., 1995). In this study. we investigate the cell cycle hypothesis further by testing whether agents known to block the cycle at specific points prevent the death of trophic factor-deprived PC12 cells and sympathetic neurons. We show that three Gl/S blockers are effective in this regard, whereas agents that block at later stages in the cycle are not.

\section{MATERIALS AND METHODS}

PCl2 cell culture. PCI2 cell cultures (passage 26-34) were maintained as described previously (Greene and Tischler, 1976: Greene et al., 1991) in RPMI 1640 medium supplemented with $10 \%$ horse serum and $5 \%$ fetal bovine scrum ( $15 \%$ serum, complete medium) and seeded on collagencoated plastic cell culture dishes (Falcon, Becton Dickinson, Franklin Lakes. NJ). For the studies involving neuronally differentiated PC12 cells, naive cells were washed free of serum by three cycles of centrifugation/ resuspension in RPMI 1640 medium. The cells then were replated onto $150 \mathrm{~mm}$ collagen-coated plastic dishes in the presence of $100 \mathrm{ng} / \mathrm{ml} \mathrm{NGF}$ and harvested for survival studies $10-14 \mathrm{~d}$ later.

Assay for PCl2 cell sumival in serum-free or NGF-free conditions. Cell survival was assayed as described previously (Batistatou and Greene, 1991; Rukenstein et al., 1991). Briefly, cells were washed extensively with serum-free RPMI 1640 ) medium ( 5 times on the dish followed by 5 cycles of centrifugation/resuspension) and replated onto collagen-coated 24well tissue culture dishes at a density of $2 \times 10^{5}$ cells/well in a volume of $1 \mathrm{ml}$ in the presence of various cell cycle blockers. Unless noted otherwise, cells were pretreated overnight $(\sim 16 \mathrm{hr}$ ) with the cell cycle blockers before serum deprivation. The drugs were not included in the cellwashing steps. At daily intervals, cells were lysed and intact nuclei were counted using a hemacytometer (Soto and Sonnenschein, 1985). In this assay, nuclei of dead cells generally disintegrate or, if in the process of apoptosis, appear pyknotic and irregularly shaped. In contrast, nuclei of living cells are phase-bright and have clearly defined limiting membranes. Cell counts were performed on triplicate wells. The data are expressed as a percentage of the cell number initially plated.

${ }^{3} \mathrm{H} /$ Thymidine incorporation. $\mathrm{PC} 12$ cells were plated in collagencoated 24-well plates at a density of $4 \times 10^{5}$ cells/well in RPMI 1640 scrum-free medium containing $3 \mu \mathrm{M}$ insulin (Sigma, St. Louis, MO) or NGF $(100 \mathrm{ng} / \mathrm{ml})$. It was necessary to add these growth factors to the serum-free cultures to prevent the control cultures from dying. Immediately after plating. cultures were treated with the indicated cell cycle blocker at various concentrations and for various lengths of time before exposure to a $1 \mathrm{hr}$ pulse of $\left[{ }^{3} \mathrm{H}\right]$ thymidine $(1 \mu \mathrm{Ci} / \mathrm{ml})$. The cultures were washed three times with $1 \mathrm{ml}$ of ice-cold PBS and then extracted with 1 $\mathrm{ml}$ of ice-cold $10 \%$ trichloroacetic acid (TCA) at $4^{\circ} \mathrm{C}$ for $1 \mathrm{hr}$. The TCA-insoluble material was solubilized overnight with $0.3 \mathrm{ml}$ of $1 \mathrm{M}$ $\mathrm{NaOH}$, transferred to a scintillation vial, neutralized with $\mathrm{HCl}$, and then quantified by liquid scintillation counting. Background counts were taken as those from cultures that had been treated with $10 \mu \mathrm{M}$ aphidicolin which, in this paradigm, routinely inhibited thymidine incorporation by $>98 \%$. Data are presented as the percentage of TCA-insoluble counts compared with those on replicate untreated control cultures. All measurements were performed in triplicate.

Nuclear staining of PC12 cells with Hoechst 33342. PC12 cells (both control and drug-treated) were deprived of serum as described above and plated on poly-1)-lysine-coated chamber slides. Twenty-four hours after plating, cells were fixed with $4 \% \mathrm{p}$-formaldehyde in PBS for $1 \mathrm{hr}$, exposed to $1 \mu \mathrm{g} / \mathrm{ml}$ Hoechst 33342 (Sigma) in PBS for $30 \mathrm{~min}$, and then rinsed once more with PBS. Cells were examined under ultraviolet illumination using a Zeiss Axiovert microscope (Thornwood, NY). Nuclei were scored as normal or pyknotic.

Alamar Blue assay for viability in senum-free medium. Serum-deprived PC12 cells were plated for assay of survival as described above. At the time of plating, $0.1 \mathrm{ml}$ of Alamar Blue solution (Alamar Biosciences, Sacramento, CA) was added to each well and cultures were placed in a $37^{\circ} \mathrm{C} \mathrm{CO} 2(7.5 \%)$ incubator for $4 \mathrm{hr}$. Next, a $0.5 \mathrm{ml}$ aliquot of medium was removed from each culture and diluted with $0.5 \mathrm{ml}$ of $\mathrm{H}_{2} \mathrm{O}$, and the difference in its absorbance at 570 and $600 \mathrm{~nm}$ was determined. Blanks consisted of culture medium containing the indicated cell cycle blocker and Alamar Blue but no cells. At subsequent time points, this procedure wals repeated on replicate plates. In this assay, living (but not dead) cells take up, metabolize, and release the dyc, causing a change in its absor- bance. Data are expressed as the percent change in absorbance compared with that obtained from cultures initially after plating. The length of incubation with Alamar Blue and the number of cells per well were closen because we had determined that the viability measurement was linear in this range. All measurements were performed in triplicate.

Culture and survival assay of sympathetic neurons. Primary cultures of sympathetic neurons were prepared from the dissociated superior cervical ganglia of postnatal day 2 rats (Lec et al., 1980). Cells were plated at a density of 0.5 ganglion/well in 24-well collagen-coated plastic dishes. Cultures were grown in RPMI 1640 medium containing $10 \%$ heatinactivated horse serum and $100 \mathrm{ng} / \mathrm{ml}$ mouse NGF. One day after plating, uridine and 5-fluorodeoxyuridine ( $10 \mu \mathrm{m}$ each) were added to the cultures and left for 3 d to climinate non-neuronal cells. On the sixth day after plating, NGF was removed by washing the cultures three times with RPMI 1640 mcdium containing $10 \%$ horse scrum, followed by the addition of $0.5 \mathrm{ml}$ of the same medium containing antibody against mouse NGF (1:200 dilution, Sigma) and the indicated cell cycle blocker. Toxicity of the pharmacological agents was assessed by re-adding $100 \mathrm{ng} / \mathrm{ml} \mathrm{NGF}$ in replicate cultures after the initial NGF washout. Viability of the neurons was assessed by counting the number of intact phase-bright ncurons in each well via strip counting (Greene et al., 1978; Rydel and Greene, 1988). Dead neurons lost their phase-bright appearance and disintegrated, leaving behind cellular debris. This determination was made on the initial day of NGF withdrawal and then on subsequent days. Results are expressed as the percentage of viable neurons compared with the percentage of those present initially after NGF withdrawal. In the studies evaluating the effectiveness of ciclopirox (CPX), neurons were cultured for only $3 \mathrm{~d}$ in the presence of NGF before its removal and the addition of CPX, because it was found that the cells died more rapidly in this paradigm.

We examined the response of the cells treated with the Gl/S blockers when the compounds were withdrawn and NGF was re-added. Neurons were grown in the presence of NGF for $3 \mathrm{~d}$, and the NGF was removed as described above and treated with the indicated agents. After $36 \mathrm{hr}$, the cultures were washed once with $1 \mathrm{ml}$ of RPMI containing $10 \%$ horse serum and then re-fed with $0.5 \mathrm{ml}$ of the same medium containing 100 $\mathrm{ng} / \mathrm{ml}$ human recombinant NGF, with which the anti-mouse NGF does not cross-react. The neurons were examined for viability as described above.

Assay of protein synthesis. Naive PC12 cells and primary sympathetic neurons were prepared and plated in 24-well collagen-coated dishes as described above. Cultures were pretreated with various concentrations of mimosine for $4 \mathrm{hr}$ before the addition of $5 \mu \mathrm{Ci}$ of $\left[{ }^{3} \mathrm{H}\right] \mathrm{leucinc} / \mathrm{well}$. After a $16 \mathrm{hr}$ incubation, the cultures were washed, TCA-extracted, solubilized, and subjected to liquid scintillation counting as described above for the measurement of $\left[{ }^{3} \mathrm{H}\right]$ thymidine incorporation. The level of background $\left[{ }^{3} \mathrm{H}\right]$ leucine incorporation was determined by pretreating replicate cultures with $1 \mu \mathrm{g} / \mathrm{ml}$ cycloheximide and subtracting the resultant value from all of the samples. In all studies, this concentration of cycloheximide caused a $>95 \%$ inhibition of $\left[{ }^{3} \mathrm{H}\right]$ leucine incorporation.

\section{RESULTS \\ Chlorphenylthio (CPT)-cAMP blocks both PC12 cell cycle progression and death}

Previous findings demonstrated that the cAMP analog CPTcAMP prevents the death of trophic factor-deprived PC12 cells and neurons (Rydel and Greene, 1988; Rukenstein et al., 1991). To examine whether this effect is related to the cell cycle, we tested the ability of CPT-cAMP to prevent DNA replication in serum-containing medium in parallel with its ability to prevent the death of serum-deprived PC12 cells. In the typical assay for serum-free survival, $65-75 \%$ of PC12 cells die after $1 \mathrm{~d}$ and virtually all die after $4 \mathrm{~d}$. As shown in Figure 1, there is a close correlation of the dose-response relationships between the ability of CPT-cAMP to inhibit thymidine incorporation and to promote the survival of PC12 cells in serum-free medium. CPT-cAMP acts rapidly to block DNA synthesis; within 2 hr of treatment with 100 $\mu \mathrm{M}$ CPT-cAMP, $\left[{ }^{3} \mathrm{H}\right]$ thymidine incorporation is blocked by $75 \%$, and inhibition is complete by $24 \mathrm{hr}$. As demonstrated previously, it is not necessary to pretreat $\mathrm{PC} 12$ cells with CPT-cAMP before 


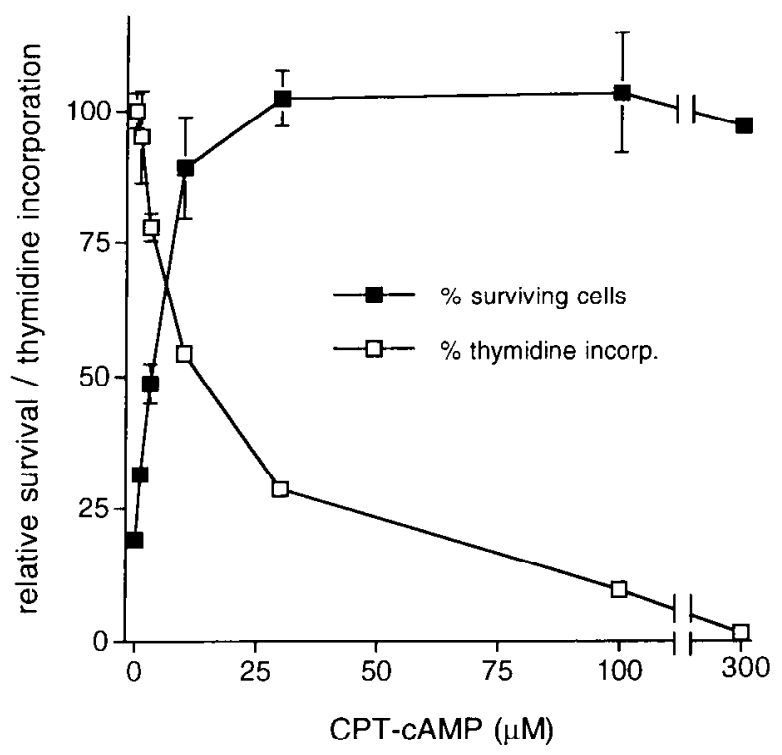

Figure 1. Dose-response relationships for promotion of survival of $\mathrm{PC} 12$ cells in serum-free medium (1 d) and inhibition of $\left[{ }^{3} \mathrm{H}\right]$ thymidine incorporation by CPT-cAMP. Cell survival data $(\mathbf{G})$ are expressed relative to the number of cells initially plated, and thymidine incorporation data ( $\square$ ) are expressed relative to untreated control cultures. For survival studies, cells were not pretreated with CPT-cAMP before serum deprivation. Assay of $\left[{ }^{3} \mathrm{H}\right]$ thymidine incorporation was conducted after a $24 \mathrm{hr}$ pretreatment with CPT-CAMP. Data are the mean \pm SEM of three samples. In this and subsequent figures, the absence of error bars indicates that the error was smaller than the symbol used.

serum deprivation to obtain complete survival (Rukenstein et al., 1991).

The finding that CPI-cAMP causes cessation of $\mathrm{PCl} 2$ cell proliferation and promotes survival prompted us to examine further the prediction that blocking ccll cycle progression may prevent cell death after trophic factor withdrawal. We therefore tested a hattery of agents that block cell cycle transit at specific points for their ability to prevent the death of trophic factordeprived PC12 cells and sympathetic neurons. All agents first were tested for their ability to block the incorporation of $\left[{ }^{3} \mathrm{H}\right]$ thymidine into DNA so that the in the experiments we would use appropriate concentrations and lengths of pretreatment.

\section{The G1/S blockers mimosine, CPX, and deferoxamine prevent the death of serum-deprived PC12 cells}

Mimosine is an agent that blocks cells before the G1/S transition point via a mechanism that is still undetemined (Lalande, 1990) (see Discussion). This drug blocks thymidine incorporation completely in dividing PC12 cells within $4 \mathrm{hr}$ at concentrations of $300-400 \mu \mathrm{M}$ (Fig. 2A) (time course of inhibition not shown). As shown in Figures $2 A$ and 3 , mimosine prevented the death of serum-deprived PC12 cells in a concentration-dependent manner and was maximally effective at $400 \mu \mathrm{m}$. Comparison of the curves in Figure $2 A$ reveals a close correlation between the concentration of mimosine required to inhibit DNA synthesis and the concentration required to prevent the death of serum deprived $\mathrm{PC} 12$ cells. Unlike rescuc by CPT-cAMP and other survival factors, it was necessary to pretreat cells with mimosine overnight before serum deprivation to obtain complete survival (Fig. 2B). Figure $2 C$ illustrates the long-term effects of mimosine treatment on survival in this paradigm. Survival up to $3 \mathrm{~d}$ was excellent $(>85 \%)$; however, mimosine was unable to promote full survival beyond this time. This seemed to be attributable to toxicity, because even when NGF was present in combination with mimosine there was a comparable loss of cell viability.

Deferoxamine is thought to block cellular proliferation before the G1/S transition by chelating intracellular iron (Brodie et al., 1993). Deferoxamine inhibits DNA synthesis in proliferating PC12 cells in a concentration-dependent manner (Fig. 4A). Treatment with $1 \mathrm{~mm}$ deferoxamine completely blocked thymidine incorporation after $4 \mathrm{hr}$. As with mimosine, there is a concentration-dependent increase in the survival of serumdeprived PC12 cells that reaches the maximum at $1 \mathrm{~mm}$ deferoxamine, the concentration at which DNA synthesis is completely abolished. As shown in Figure $4 B$, deferoxamine treatment produces good short-term survival in this paradigm compared with survival in untreated cultures. After long-term exposure, however, deferoxamine, like mimosine, proves toxic to the cells because viability cannot be mainlained even when NGF is provided in combination. Overnight pretreatment enhances the protective effect of deferoxamine on serum-deprived PC12 cells (Fig. 4C). Deferoxamine-treated cells deprived of serum for $1 \mathrm{~d}$ are shown in Figure $3 D$.

CPX blocks cells at the same point near the G1/S border as does mimosine, but its mechanism of action is unknown (Hoffman et al., 1991). CPX inhibits thymidine incorporation in PC12 cells with an $\mathrm{IC}_{50}$ of $\sim 1.5 \mu \mathrm{M}$ in serum-free medium and an $\mathrm{IC}_{50}$ of $\sim 5$ $\mu \mathrm{M}$ in medium containing $15 \%$ serum. In serum-free medium, there was a reproducible increase in $\left[{ }^{3} \mathrm{H}\right]$ thymidine incorporation with $1 \mu \mathrm{M}$ CPX before the steep decline; at $2 \mu \mathrm{M}$ CPX, inhibition of DNA synthesis was virtually complete (Fig. 5A). After overnight pretreatment of $\mathrm{PC} 12$ cells growing in serum-containing medium with $10 \mu \mathrm{M} \mathrm{CPX}$, the drug was able to promote ncarly complete survival $24 \mathrm{hr}$ after serum deprivation, and it did so at concentrations similar to those required to inhibit $\left[{ }^{3} \mathrm{H}\right]$ thymidine incorporation (Fig. $5 A$ ). As with mimosine and deferoxamine, it was necessary to pretreat cells with CPX before serum deprivation to obtain maximal survival. Figure $5 B$ depicts the time course of the effects of CPX treatment on survival in this paradigm. Survival was good up to $2 \mathrm{~d}$ after serum deprivation ( $>75 \%$ survival); however, CPX was unable to maintain good long-term survival. This seemed to be attributable to the toxicity of the drug, because even when NGF was present in combination with CPX there was a similar loss of cell viability.

In addition to cell counting, several independent methods were used to confirm the viability of the cells treated with the G1/S blockers. These are presented in Figure 6. Cultures were maintained in serum-free medium with mimosine for $1 \mathrm{~d}$ and then washed free of the drug and returned to medium containing $15 \%$ serum. Under these conditions, after a lag phase for the cells that had been maintained by mimosine, proliferation recommenced, thus providing a clear indication of viability (Fig. 6 $\mathrm{A}$ ). The lag phase presumably reflects the time required for the drug to be cleared from the cells. We also used the vital indicator Alamar Blue, a dye that is reduced by living cells, to examine the extent of cell survival. The data in Figure $6 B$ indicate that by this criterion all three $G 1 / S$ blockers maintained full cell viability in serum-free medium. In addition, nuclear morphology of serum-deprived PC12 cells (exposed to no additive, NGF, CPX, mimosine, or deferoxamine for $24 \mathrm{hr}$ ) was visualized using the stain Hoechst 33342. Quantitation of normal and pyknotic nuclei provided results similar to those achieved by the counting of intact nuclei. In this assay, the proportions of cells with pyknotic nuclei $(n=$ 

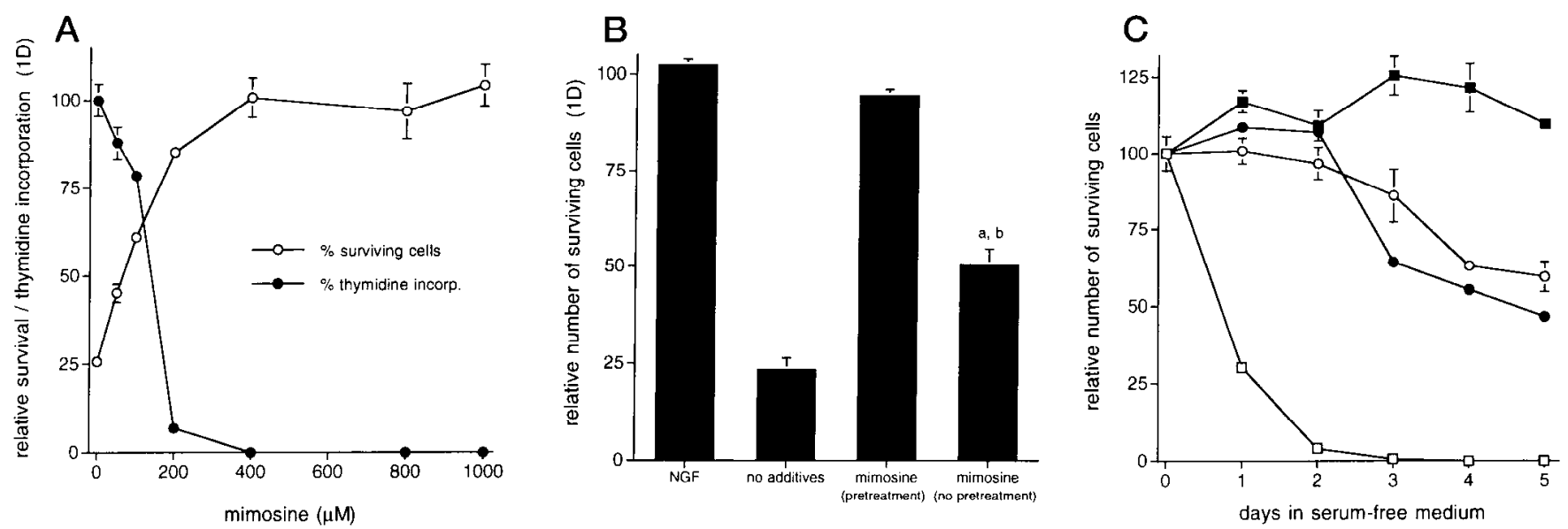

Figure 2. Mimosine promotes survival of $\mathrm{PC} 12$ cells in serum-free medium and inhibits [3II]thymidine incorporation. $A$, Dose-response relationships for promotion of survival at $1 \mathrm{~d}$ and inhibition of thymidine incorporation by mimosine. For survival studies $(O)$, cells were pretreated with mimosine for $16 \mathrm{hr}$ before serum deprivation. Assay of $\left[{ }^{3} \mathrm{H}\right]$ thymidine incorporation (@) was conducted after a $24 \mathrm{hr}$ pretreatment with mimosine. $B$. Pretreatment with mimosine enhances its protective effect on serum-deprived PC12 cells. Pretreated cells were exposed to $400 \mu \mathrm{M}$ mimosine for $16 \mathrm{hr}$ before serum-deprivation; $a$ indicates significantly greater than untreated control $(p<0.05)$; $b$ indicates significantly less than mimosine-pretreated cultures $(p<0.05)$. C, Time course of survival in serum-free conditions: $(\square)$ no additives; $(\square)$ NGF; $(O) 400 \mu \mathrm{M}$ mimosinc: (-) $400 \mu \mathrm{M}$ mimosine + NGF. All data are the mean \pm SEM of three samples.

$100-200$ nuclei/treatment) were as follows: $56 \%$, no additive; $9 \%$, NGF; $9 \%, \mathrm{CPX} ; 11 \%$, deferoxamine; and $11 \%$, mimosine.

Because mimosine is an amino acid and was used at relatively high concentrations, we determined whether this agent might prevent cell death by interfering with protein synthesis. The data in Figure $6 C$ show that mimosine does not inhibit protein synthesis by $>15-20 \%$ in either $\mathrm{PC} 12$ cells or primary sympathetic neurons at concentrations up to $800 \mu \mathrm{M}$. Martin et al. (1992) reported that cell death was prevented by cycloheximide in NGFdeprived sympathetic neuron cultures only when protein synthesis was blocked by $\geq 80 \%$. Thus, mimosine does not promote survival by inhibiting protein synthesis.

\section{S-, G2-, or M-phase blockers do not prevent the death of serum-deprived naive PC12 cells}

The three S-phase blockers chosen for these studies inhibit distinct enzymes necessary for DNA synthesis: aphidicolin inhibits DNA polymerase- $\alpha$ (Ikegami et al., 1978); 5-fluorodeoxyuridine inhibits thymidylate synthetase (Jackson, 1978); and hydroxyurea blocks ribonucleotide reductase (Adams and Lindsay, 1967). We used the following concentrations: $10 \mu \mathrm{M}$ aphidicolin, $10 \mu \mathrm{M}$ 5 -fluorodeoxyuridine, and $3 \mathrm{~mm}$ hydroxyurea. Al these concentrations, DNA synthesis was inhibited $>95 \%$ after $3 \mathrm{hr}$. None of the S-phase blockers, however, were able to prevent the death of serum-deprived PC12 cells (Fig. $7 A$ ). These blockers were ineffective regardless of the length of the pretreatment period (up to $3 \mathrm{~d}$ before serum withdrawal; data not shown). Addition of NGF to the cultures maintained their survival in the presence of the inhibitors, indicating that the drugs themselves did not cause cell death.

The topoisomerase inhibitor VM-26 blocks cells in the G2phase of the cell cycle (Roberge et al., 1990; Chen and Beck, 1993). Nocodazole and taxol, agents that inhibit and stabilize polymerization of microtubules, respectively, block cells in mitosis (Schiff et al, 1979; Wilson and Jordan, 1994). Each of these agents blocks DNA synthesis but, in contrast to the other agents used here, the $\mathrm{M}$-phase inhibitors required $2 \mathrm{~d}$ of pretreatment before causing complete inhibition of thymidine incorporation. This was expected because the PC12 cell cycle lasts $\sim 2.5 \mathrm{~d}$, with the $\mathrm{M}$-phase taking only a small fraction of that. Preliminary investigations revealed that the concentrations of VM-26, nocodazole, and taxol required to block DNA synthesis were $1 \mu \mathrm{M}, 200 \mathrm{~nm}$, and $500 \mathrm{~nm}$, respectively. As with the S-phase blockers, G2-phase and mitotic inhibitors failed to prevent the death of $\mathrm{PC} 12$ cells after serum withdrawal (Fig. $7 B$ ). 'I hese blockers were ineffective regardless of the length of pretreatment (up to $3 \mathrm{~d}$; data not shown). In this paradigm, NGF substantially prevented the death of $\mathrm{PC} 12$ cells in the presence of the inhibitors. The capacity of NGF to rescue cells blocked in the S-, G2-, or M-phase contrasts with the suggestion that NGF actions are limited to a particular phase of the cell cycle (Rudkin et al., 1989).

\section{Neuronally differentiated PC12 cells}

Mimosine, deferoxamine, and CPX prevent the death of neuronal PC12 cells after removal of NGF

We next tested whether cell cycle blockers prevented the death of PC12 cells that were neuronally differentiated by long-term treatment with NGF in serum-free medium and then deprived of the factor. After several days in serum-free medium with NGF, PC12 cells stop dividing and acquire many of the phenotypic properties of sympathetic neurons (Greene and Tischler, 1982). Serum-deprived neuronal PC12 cells, like sympathetic neurons, die after NGF withdrawal, with $\sim 50-60 \%$ of the cells dead after $2 \mathrm{~d}$. The addition of $400 \mu \mathrm{M}$ mimosine, $1 \mathrm{~mm}$ deferoxamine, or $1.5 \mu \mathrm{M}$ CPX to cultures of neuronal PC12 cells after the cells were washed free of NGF caused nearly complete survival for up to $2 \mathrm{~d}$ and $\sim 80 \%$ survival at $3 \mathrm{~d}$. In contrast, only $25 \%$ of untreated cells remained viable at the latter time (Fig. 8). After $2-3 \mathrm{~d}$ in the absence of $\mathrm{NGF}$, there was a gradual decrease in the number of cells maintained by the three drugs. This seemed to be attributable to the toxic effects of these agents (Fig. 8). Unlike naive PC12 cells deprived of serum, it was not necessary to pretreat neuronal PC12 cells with mimosine or deferoxamine before NGF withdrawal to obtain complete survival. In the 

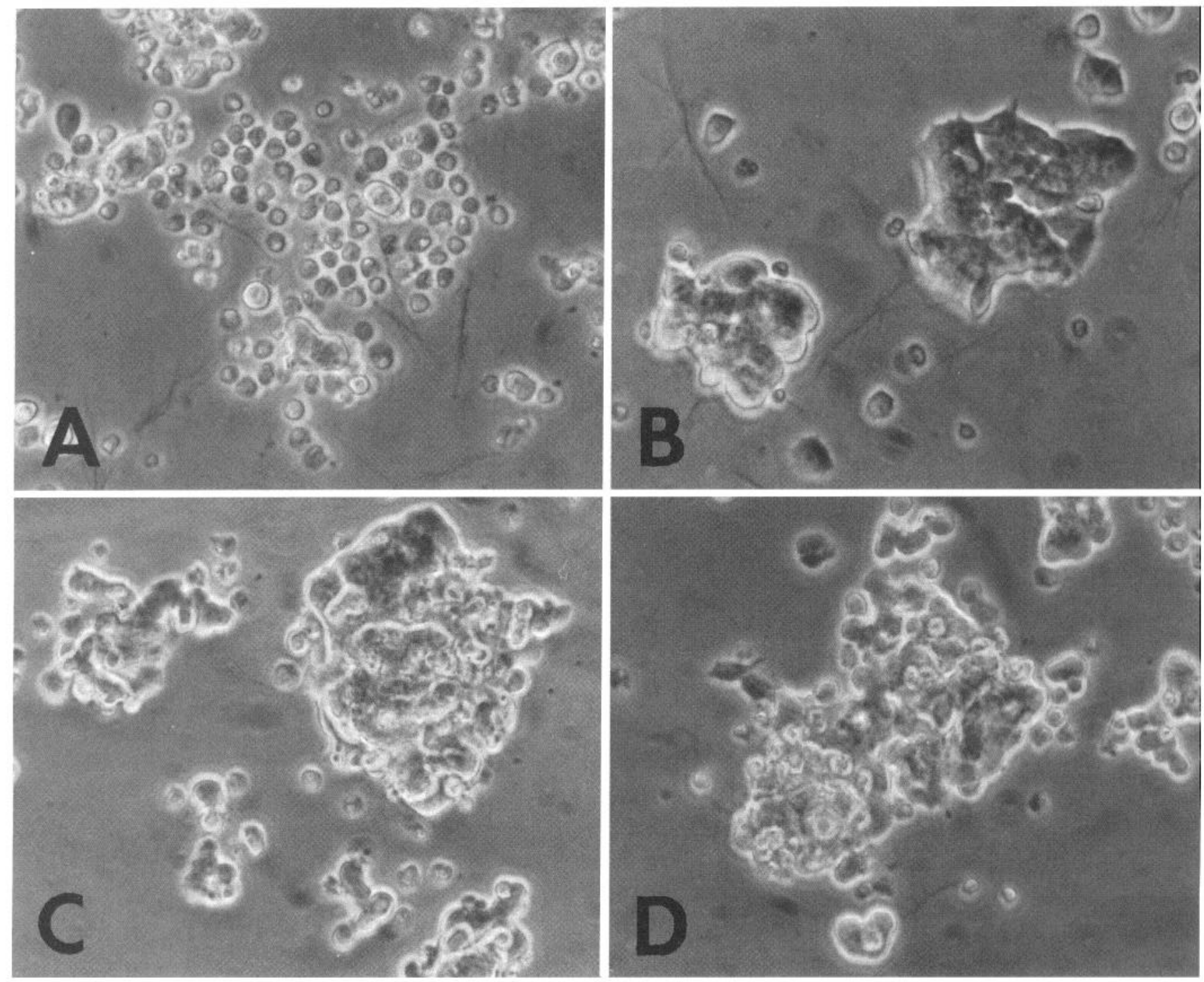

Figure 3. Phase-contrast micrographs of PC12 cells maintained in serum-free conditions for $24 \mathrm{hr}$ with $(A)$ no additives, $(B) 100 \mathrm{ng} / \mathrm{ml} \mathrm{NGF}$, (C) 400 $\mu \mathrm{M}$ mimosine, and $(D) 1 \mathrm{~mm}$ deferoxamine. Magnification, $375 \times$.

absence of NGF, these three agents did not promote neurite regeneration-nor did they prevent this process in the presence of NGF (data not shown).

\section{$S-, G 2-$, or M-phase blockers do not prevent the death of} neuronal PC12 cells after the removal of NGF

We proceeded to test the ability of the other cell cycle blockers to prevent the death of NGF-deprived neuronal PC12 cells. The data in Figure 7, $C$ and $D$, show that S-, G2-, or M-phase blockers do not rescue these cells from death. Cells treated with $S$-phase blockers die at the same rate as untreated controls do, whereas cells that received $\mathrm{NGF}$ in addition to the inhibitor were mostly protected (Fig. $7 C$ ). Figure $7 D$ shows basically the same outcome with G2- and M-phase inhibitors. Two days after NGF removal, roughly the same fraction of cells died, despite the presence of these agents. NGF rescued the cells from death under all conditions, demonstrating that the inhibitors themselves were not toxic in this paradigm. None of the inhibitors was able to prevent cell death, even when the cultures were pretreated up to $3 \mathrm{~d}$ before NGF withdrawal (data not shown).

\section{Primary sympathetic neurons}

G1 blockers mimosine, deferoxamine, and CPX prevent the death of sympathetic neurons after removal of $N G F$, whereas $S$-, G2-, and M-phase blockers do not

Our observations with neuronal PC12 cells indicate that mimosine, deferoxamine, and CPX prevent the death of cells that are nonmitotic at the time of NGF withdrawal. To extend these observations to a postmitotic neuronal model, we next examined the effects of cell cycle blockers on NGF-deprived sympathetic neurons. In this paradigm, sympathetic neurons from 2-d-old rats were cultured in the presence of NGF for $6 \mathrm{~d}$ (or $3 \mathrm{~d}$ in the CPX experiments) and then deprived of the factor. Under these conditions, $\sim 50-60 \%$ of the neurons die within $48 \mathrm{hr}$ and virtually all die by $5 \mathrm{~d}$. The addition of mimosine, deferoxamine, or CPX to cultures of sympathetic neurons immediately after NGF withdrawal rescued them from death (Figs. 9, 10). The dose-response relationships for neuronal survival (data not shown) correlated well with those observed for naive $\mathrm{PC} 12$ cell survival after serum deprivation (see Figs. $2 A, 4 A, 5 A$ ), which is consistent with the 

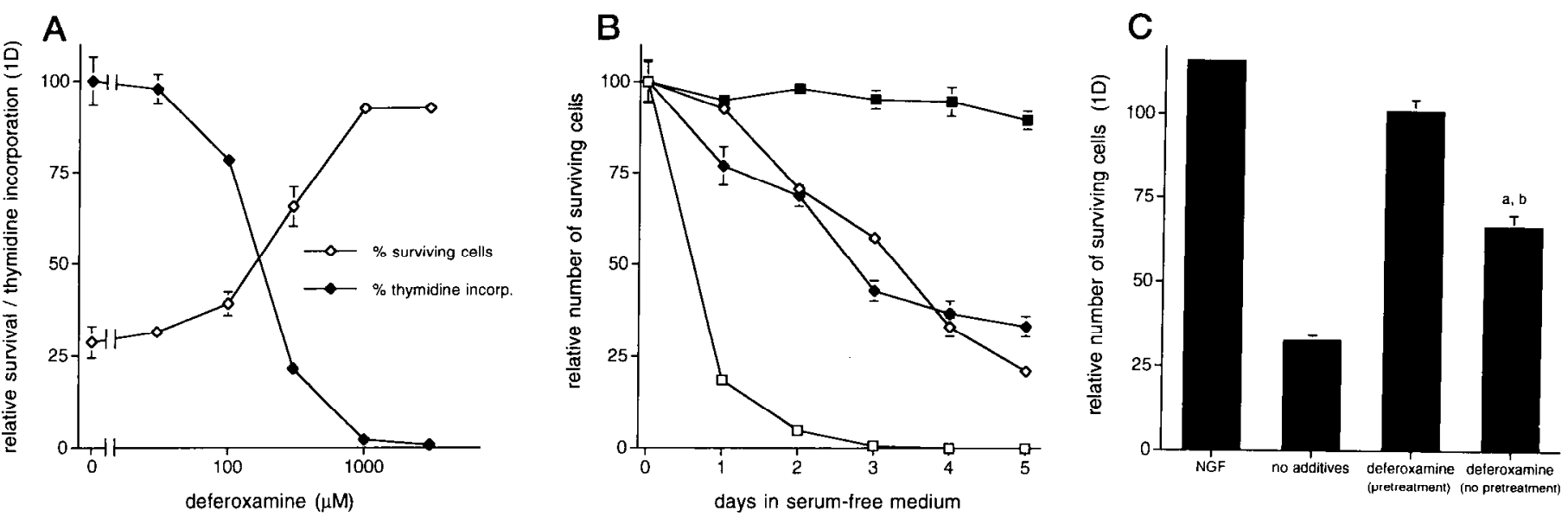

Figure 4. Deferoxamine promotes survival of PC12 cells in serum-free medium and inhibits [ $\left.{ }^{3} H\right]$ thymidine incorporation. $A$, Dose-respunse relationships for promotion of survival at $1 \mathrm{~d}$ and inhibition of thymidine incorporation by deferoxamine. For survival studies $(\diamond)$, cells were pretreated with deferoxamine for $16 \mathrm{hr}$ before serum deprivation. Assay of $\left[{ }^{3} \mathrm{H}\right.$ |thymidine incorporation $(\bullet)$ was conducted after a $24 \mathrm{hr}$ pretreatment with deferoxamine. $B$, Time course of survival in serum-free conditions: $(\square)$ no additives; $(\square)$ NGF; $(\diamond) 1 \mathrm{~mm} \mathrm{deferoxamine;}(\bullet)$ $1 \mathrm{~mm}$ deferoxamine + NGF. $C$, Pretreatment with deferoxamine enhances its protective effect on serum-deprived PC12 cells. Pretreated cells were exposed to $1 \mathrm{~mm}$ deferoxamine for $16 \mathrm{hr}$ before serum deprivation: $a$ indicates significantly greater than untreated control $(p<0.05) ; b$ indicates significantly less than deferoxamine-pretreated cultures $(p<0.05)$. All data are the mean \pm SEM of three samples.

possibility that the mechanism of rescue is similar in the two systems. After $3 \mathrm{~d}$ of deprivation, $-80 \%$ of the mimosine-treated neurons, $90 \%$ of the deferoxamine-treated neurons, and $>95 \%$ of the CPX-treated neurons retained a phase-bright, viable appearance compared with $<25 \%$ of their untreated counterparts. Although the neurons in cultures treated with these agents showed loss of somal volume, they maintained their neurite network in the absence of $\mathrm{NGF}$, in contrast to the dying, untreated controls (Fig. 10). As shown in Figure $6 C$, the effect of mimosine was not attributable to suppression of protein synthesis. Nlthough both agents maintained survival, they did not promote somatic hypertrophy as did NGF (Fig. 10B). Viability of the neurons began to decline after $3 \mathrm{~d}$ in the presence of either agent. As with PC12 cells, this seemed to be attributable to a long-term toxic action of these agents, because the cells die even if NGF is present in combination with these drugs (Fig. 9A-C). This toxicity was concentration-dependent (data not shown).

To verify that the neurons maintained by the G1/S blockers were indeed viable, the drugs were removed and NGF was added to the cultures again. As observed by microscopic inspection, removal of the blockers and addition of NGF were accompanied by the return of somatic hypertrophy and by renewed outgrowth of the neuritic network. Moreover, as shown in Figure 9D, quantification revealed that the majority
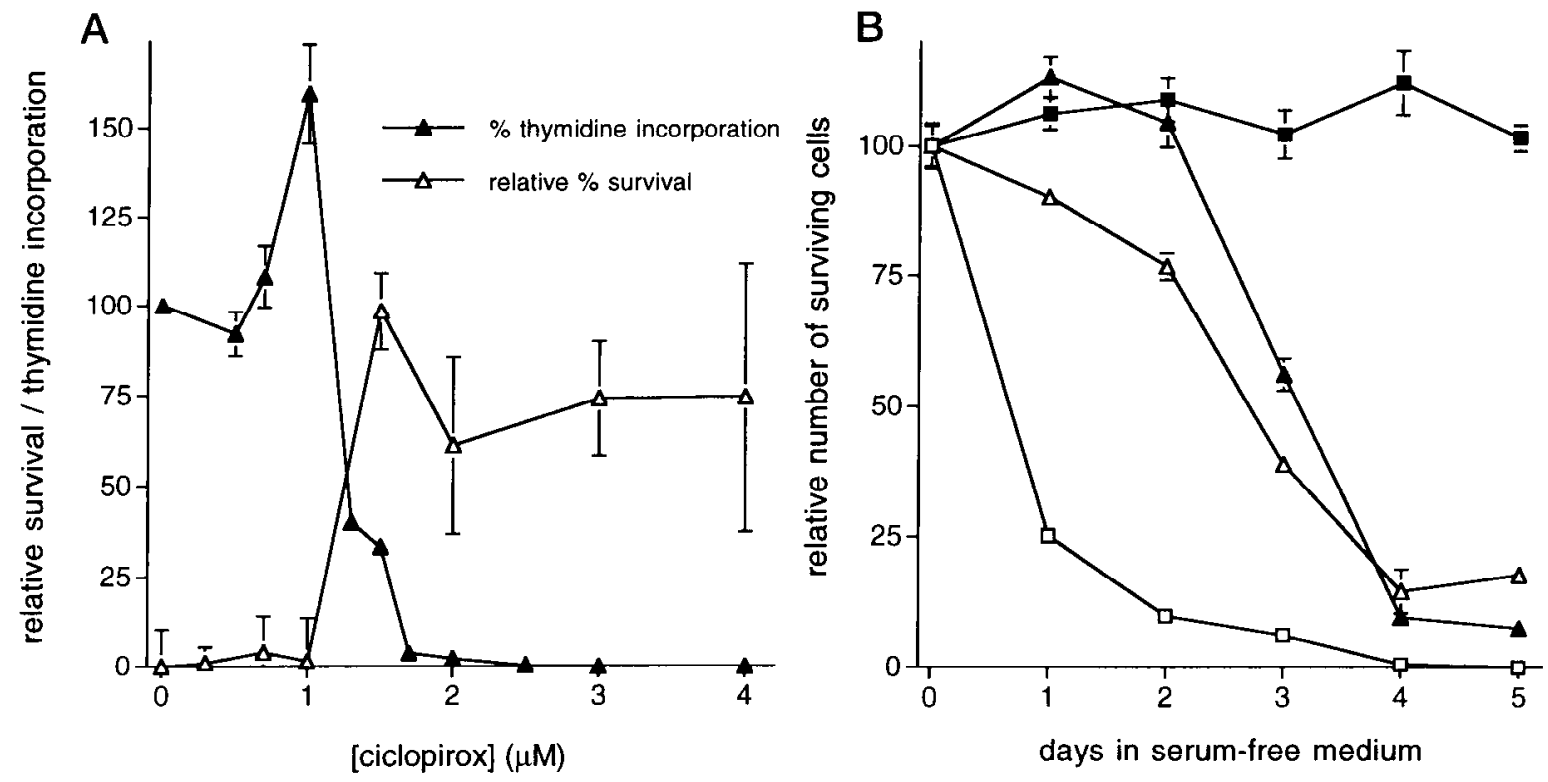

Figure 5. CPX promotes survival of PC12 cells in serum-free medium and inhibits $\left[{ }^{3} \mathrm{H}\right]$ thymidine incorporation. $A$, Dose-response relationships for promotion of survival at $1 \mathrm{~d}$ and for inhibition of thymidine incorporation $(\mathbf{\Delta})$. For survival studies $(\triangle)$, CPX-treated cells also were pretreated with 10 $\mu \mathrm{M} \mathrm{CPX}$ for $16 \mathrm{hr}$ before serum deprivation. Survival data are normalized so that the survival without CPX is set at zero. Assay of $\left[{ }^{3} \mathrm{H}\right] \mathrm{thymidine}$ incorporation was conducted in serum-free conditions with NGF after a $24 \mathrm{hr}$ pretreatment with the indicated concentration of CPX. $B$, Time course of

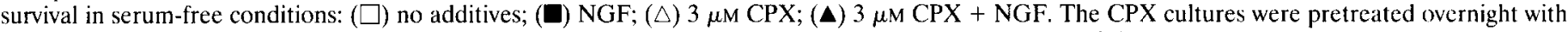
$10 \mu \mathrm{M}$ CPX and replated in serum-free medium containing $3 \mu \mathrm{M}$ CPX. All data are the mean \pm SEM of three samples. 

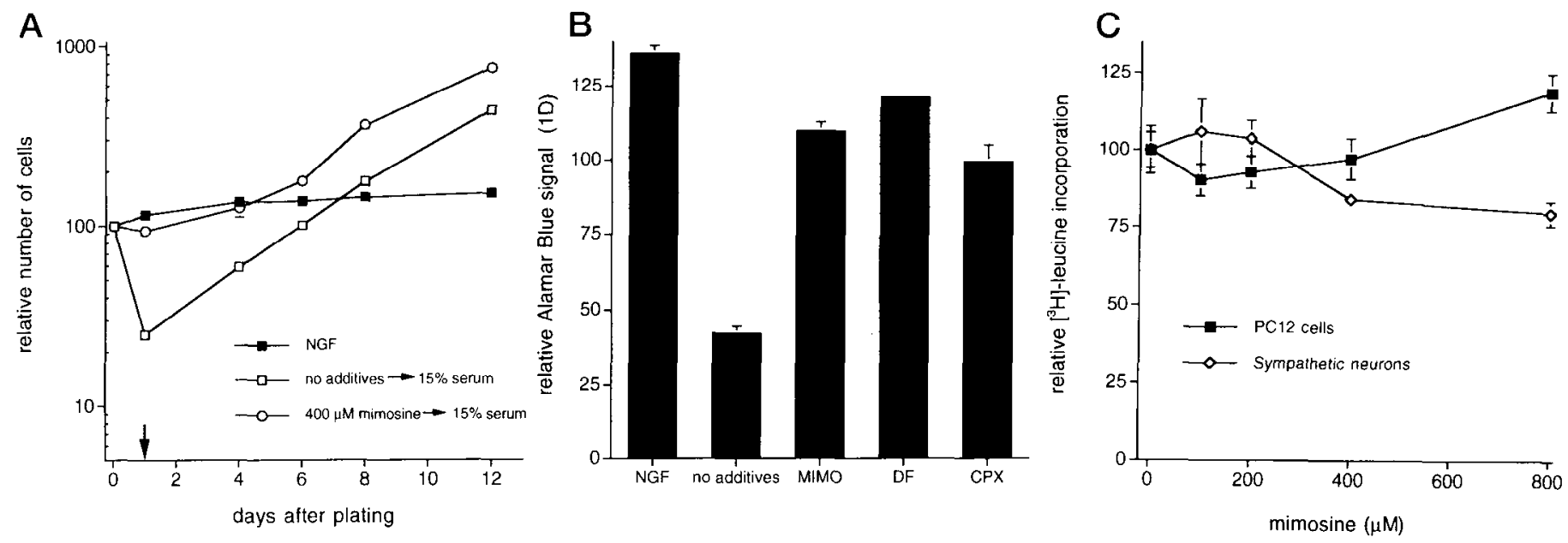

Figure 6 . Viability of cells cultured with $\mathrm{Gl}$ blockers. $A$, Reversibility. Cells were cultured for $24 \mathrm{hr}$ in serum-free medium with (O) or without ( $\square$ ) 400 $\mu \mathrm{M}$ mimosine and then with medium containing $15 \%$ serum. Cells maintained continuously in serum-free medium containing NGF (D) are shown for reference. Cell numbers were determined at the indicated times and are expressed on a semilog plot relative to the number initially plated (day 0 , arrow'). $B$. Metabolism. Replicate cultures were maintained for $24 \mathrm{hr}$ in serum-frec medium with $N G F$, no additives, $400 \mu \mathrm{M}$ mimosine $(M I M O)$ ). 1 mm deferoxamine $(D F)$, or $3 \mu \mathrm{M} C P X$ and then assessed for Alamar Blue metabolism as described in Materials and Methods. The data for each treatment group are normalized to the signal obtained from replicate cultures immediately after plating. C, Protein synthesis. Cultures of PC 12 cells ( $\square$ ) and sympathetic neurons $(\diamond)$ were pretreated with the indicated concentrations of mimosine for $4 \mathrm{hr}$ and then incubated for an additional 16 hr with mimosine and $\left.\mid{ }^{3} \mathrm{H}\right]$ leucine. Cultures then were assayed for $\left[{ }^{3} \mathrm{H}\right] \mathrm{keucine}$ incorporation as described in Materials and Methods. Data are expressed relative to untreated control cultures. All data are the mean \pm SEM of three samples.

of neurons initially maintained by the blockers continued to survive with NGF.

As illustrated in Figure $9 E$, treatment of sympathetic neurons with S-, G2-, and M-phase blockers did not effectively rescue them from death after NGF withdrawal. These blockers were not toxic to the neurons, because viability was maintained when NGF was present in combination.

\section{DISCUSSION}

We demonstrate here that mimosine, CPX, and deferoxamine inhibit death of trophic factor-deprived PC12 cells and sympathetic neurons. These findings, therefore, identify several small compounds that interfere with induced neuronal death and provide potential insight into the mechanisms by which trophic agents regulate neuronal survival and apoptosis.

The capacity of $G 1 / \mathrm{S}$ blockers to maintain survival was confirmed by several different criteria. For PC12 cells, quantification of intact nuclei. which has proved a highly reliable indicator of survival in previous studies (Batistatou and Greene, 1991; Rukenstcin et al., 1991), was supplemented by demonstrating intact metabolic function with Alamar Blue, showing that cell replication commenced after drug washout and addition of serum, and differentially staining intact and pyknotic nuclei with Hoechst 33342. In the case of sympathetic neurons, cell survival was assessed by the presence of intact, phase-bright somas and maintenance of the neuritic network, as well as by the observation that drug washout and NGF re-addition led to the reappearance of neurite outgrowth and somatic hypertrophy. Moreover, a majority of cells scored as viable in the presence of the G1/S inhibitors were still identifiable as such several days after the drugs were removed and replaced with $\mathrm{NGF}$.

One mechanism that might account for the protective effects of mimosine, CPX, and deferoxamine is their action as cell cycle inhibitors. We have hypothesized that trophic factors such as NGF promote survival by guiding proliferating neuroblasts through the cell cycle, by causing neuroblasts to differentiate and leave the cycle, or by causing postmitotic neurons to remain out of the cycle (Ferrari and Greene, 1994; Greene et al., 1995a,b). We and others have postulated further that neuroblast-like cells dic after loss of trophic support because they undergo an aborted attempt to proliferate, and that withdrawal of trophic factors from postmitotic neurons causes apoptotic death attributable to an inappropriate attempt to re-enter the cell cycle (Batistatou and Greene, 1993; Heintz, 1993; Rubin et al., 1993; Ferrari and Greene, 1994; Freeman et al., 1994; Greene et al., 1995a,b). I' that appropriately blocking neuronal cells from entering or reentering the cell cycle should protect them from death caused by loss of trophic support. In accordance with this, blockade of DNA synthesis by induction of dominant-inhihitory ras in both naive and primed PC12 cells (Ferrari and Greene, 1994) or by treatment of $\mathrm{PC} 12$ cells and sympathetic neurons with $\mathrm{N}$-acetylcysteine (Ferrari et al., 1995) promotes long-term survival after trophic factor withdrawal. Our experiments further support and extend these findings.

One question that was answered here is whether blockade at any stage of the cell cycle is sufficient to prevent death of trophic factor-deprived neuronal cells. Clearly, our findings indicate that this is not the case. S-, G2-, or M-phase blockers werc unable to delay or prevent death. Only Gl/S blockers were effective in this respect. This suggests that there is a cell cycle checkpoint downstream of or at the point where these agents block (i.c., near the G1/S border) that, once passed, commits neuronal cells to die in the absence of trophic support. cAMP is also an effective Gl blocker (Boynton and Whitfield, 1983; Kato et al., 1994), and our observed close correspondence between the dose-response curves for inhibition of DNA synthesis and promotion of survival by CPT-cAMP also supports this idea.

We used three complementary neuronal death models: proliferating naive $\mathrm{PC} 12$ cells, nonproliferating neuronally differentiated PC12 cells, and postmitotic sympathetic neurons. Several points that support the above interpretation emerge from com- 

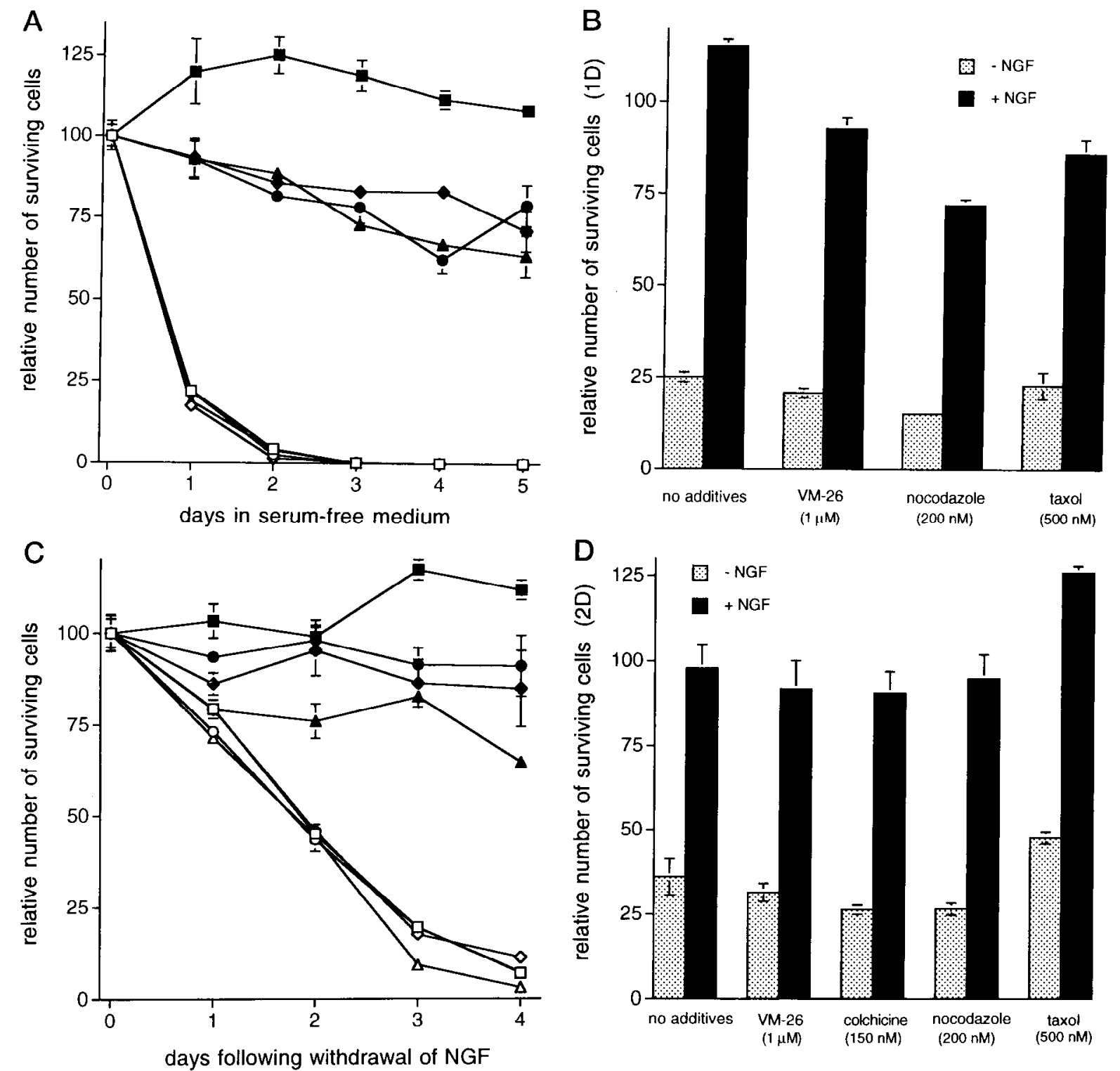

Figure 7. S-, G2-, and M-phase blockers do not prevent the death either of naive PC12 cells in serum-free conditions or of neuronal PC12 cells after NGF withdrawal. $A, B$, Serum-deprived naive PC12 cells. Cultures were pretreated with the indicated agent for $16 \mathrm{hr}$ before serum deprivation. $A$, DNA synthesis inhibitors: $(\square)$ no additives; $(\mathbf{Q}) \mathrm{NGF} ;(\bigcirc) 10 \mu \mathrm{M}$ aphidicolin; $(\bullet) 10 \mu \mathrm{M}$ aphidicolin $+\mathrm{NGF},(\diamond) 10 \mu \mathrm{M}$-fluorodeoxyuridine; $(\$) 10 \mu \mathrm{M}$ 5-fluorodeoxyuridine + NGF; $(\triangle) 3 \mathrm{mM}$ hydroxyurea; (A) hydroxyurea + NGF. B, G2- and M-phase blockers (VM-26, nocodazole, taxol). Meshed bars indicate no NGF; filled bars indicate added NGF. $C, D$, NGF-deprived neuronally differentiated PC12 cells. PC12 cells were neuronally differentiated by treatment with NGF for 10-14 d in serum-free medium. PC12 cells were washed free of NGF and replated in the presence of the indicated agent. Cultures were not pretreated with agents before NGF withdrawal. $C$, DNA synthesis inhibitors: $(\square)$ no additives; (ロ) NGF; (O) $10 \mu \mathrm{M}$ aphidicolin; $(\bullet)$ 10 $\mu \mathrm{M}$

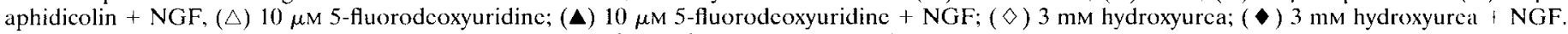
D, G2- and M-phase blockers (VM-26, colchicine, nocodazole, taxol) ( $2 \mathrm{~d}$ after NGF withdrawal). Cell survival data are expressed relative to the number initially plated. Meshed bars indicate no NGF; filled bars indicate added NGF. All data are the mean \pm SEM of three samples.

parison of the three systems. First, the dose-response relationships for cell cycle blockade by mimosine, CPX, and deferoxamine in naive PC12 cells correlate well with the abilities of these drugs to rescue all three cell types from death. This not only supports a link between cell cycle and neuronal death, but it is also consistent with a mechanism by which neuronally differentiated $\mathrm{PC} 12$ cells and sympathetic neurons re-enter the cell cycle after withdrawal of trophic support but are prevented by these agents from fatally progressing. Second, complete rescue of naive $\mathrm{PC} 12$ cells by the Gl blockers requires overnight pretreatment before serum deprivation, whereas such pretreatment is not necessary for complete rescue of neuronally differentiated $\mathrm{PC} 12$ cells or sympathetic neurons. This difference is in agreement with the prediction of a critical checkpoint before the $\mathrm{Gl} / \mathrm{S}$ border. Without drug pretreatment, naive $\mathrm{PC} 12$ cells are unsynchronized, and at the time of trophic factor withdrawal, portions of the PC12 cells are in the $S$-, G2-, or M-phase. Our findings indicate that cells allowed to enter these portions of the cycle dic when deprived of trophic support. On the other hand, with a pretreatment period with $\mathrm{Gl} / \mathrm{S}$ blockers, the cells have the time to continue progression so that they return to $\mathrm{Gl}$ where they are then trapped in a safe position before the critical checkpoint. Thus, as observed, pretreatment is necessary for complete rescue of naive cells from serum withdrawal. In this case of sympathetic neurons and neuronally differentiated 

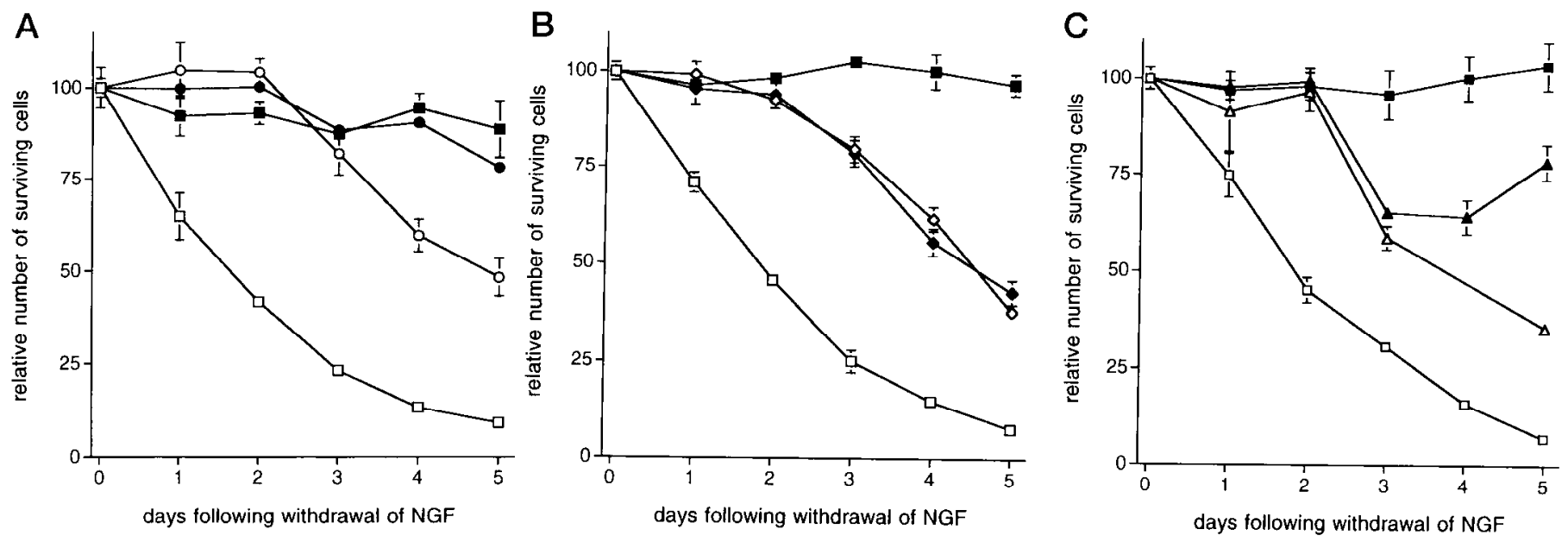

Figure 8. G1 blockers prevent the death of neuronally differentiated PC12 cells in serum-free medium after removal of NGF. PC12 cells were differentiated by treatment with NGF for 10-14 d in serum-free medium. PC12 cells were washed free of NGF and replated in the presence of the indicated agent. Cultures were not pretreated with agents before NGF withdrawal. $A$, Effects of mimosine on NGF-primed PC12 cell survival after removal of NGF in serum-free medium: $(\square)$ no additives; $(\square)$ NGF; $(O) 400 \mu \mathrm{m}$ mimosine; $(\bullet) 400 \mu \mathrm{M}$ mimosine + NGF. $B$, Effects of deferoxamine on NGF-primed PC12 cell survival after removal of NGF in serum-free medium: $(\square)$ no additives; $(\boldsymbol{Q}) \mathrm{NGF} ;(\diamond) 1 \mathrm{~mm}$ deferoxamine; $(\diamond) 1 \mathrm{~mm}$

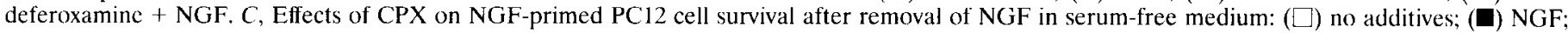
( $\triangle) 1.5 \mu \mathrm{M} \mathrm{CPX} ;(\triangle) 1.5 \mu \mathrm{M}$ CPX + NGF. Cell survival data are expressed relative to the number initially plated. All data are the mean \pm SEM of three samples.

PC12 cells, the cells are already essentially synchronized in $G_{0}$ in the presence of NGF, and pretreatment is therefore unnecessary for complete rescue by $\mathrm{G} 1 / \mathrm{S}$ blockers.

The above interpretations are supported further by observations regarding apoptosis of mature $\mathrm{T}$ lymphocytes induced by $\mathrm{T}$ cell receptor ( $T c R)$ agonists. Susceptibility to TcR agonists occurs only when $T$ cells are induced to proliferate by growth factors such as interleukin (IL)-2 (I.enardo, 1991). Boehme and I enardo (1993) reported that IL-2-treated mature $T$ lymphocytes were rescued from TcR-induced apoptosis by the G1 inhibitors mimosine, deferoxamine, and dibutyryl cAMP but not by the S-phase inhibitor aphidicolin.

The mechanisms by which mimosine and deferoxamine block proliferation are unclear, but it seems that their ability to chelate metal ions is critical. Mimosine is a plant amino acid that chelates copper and iron (Hashiguchi and Takahashi, 1977; Kontoghiorghes and Evans, 1985). It reversibly inhibits the metallo-enzyme deoxyhypusyl hydroxylase, thus preventing the formation of hypusine, an essential component of the eukaryotic initiation factor 5A (Hanauske-Abel et al., 1994). There is evidence for a correlation between hypusine formation and cell cycle progression (Park et al., 1993). It also has bcen reported that mimosine causes a decrease in cyclin $\mathrm{A} / \mathrm{p} 34^{\mathrm{cdc} 2}$ kinase activity (Carbonaro-Hall et al., 1993; Feldman and Schonthal, 1994) as well as in the corresponding mRNAs for cyclin $\mathrm{A}$ and $\mathrm{p} 34^{\mathrm{cdc} 2}$ (Feldman and Schonthal, 1994). Deferoxamine is a microbial siderophore that has a high affinity for iron. Proliferating cells have an essential requirement for iron, and iron chelators such as deferoxamine block DNA synthesis (Robbins and Pederson, 1970; Ganeshaguru et al., 1980) and halt the cell cycle before the G1/S boundary (Terada et al., 1991). Deferoxamine also prevents the synthesis of p34 ${ }^{\mathrm{cdc} 2}$ in both lymphocytes and neuroblastoma cells (Brodie et al., 1993; Terada et al., 1993). The mechanism by which CPX blocks cell cycle progression is not known (Hoffman et al., 1991). It is used clinically as a topical antifungal agent, and its action in this respect may involve disruption of membrane function in sensitive organisms (Jue et al., 1985). Because of its structural similarity with mimosine, the possibility that CPX chelates metal ions and/or inhibits hypusine formation cannot be excluded, although no such evidence has been reported (Hoffman et al., 1991; Hanauske-Abel et al., 1994).

Because mimosine and deferoxamine are metal chelators, it is prudent to consider the possibility that they promote survival by inhibiting the formation of reactive oxygen species (ROS). There is reason to consider possible links between oxidative stress and neuronal apoptosis caused by trophic factor withdrawal. GreenIund et al. (1995) reported that there is a transient increase in ROS in sympathetic neurons within hours of NGF withdrawal. Moreover, the latter found that microinjection of copper/zinc superoxide dismutase (SOD) protein or expression vector delayed death of neurons deprived of NGF, whereas injection of antisense SOD accelerated neuronal death. Because re-addition of NGF was able to rescue NGF-deprived sympathetic neurons at a point after which injection of SOD cannot, it was suggested that generation of ROS signals downstream events in neuronal programmed cell death (Greenlund et al., 1995). In additional studies, it was observed that trophic agents can protect neurons from conditions that cause oxidative stress, that such agents enhance metabolic pathways by which neurons cope with oxidative stress (Boniece and Wagner, 1993; Pan and Perez-Polo, 1993), and that overexpression of $b c l-2$ provides protection from both oxidative stress (Kane et al., 1993) and loss of trophic support (Garcia et al., 1992; Batistatou et al., 1993; Mah et al., 1993). In addition, Ratan et al. (1994a,b) showed that inhibitors of protein and RNA synthesis protect neurons from apoptosis caused either by withdrawal of growth factors or by induction of oxidative stress by shunting intracellular use of cysteine from protein synthesis to that of glutathione, a major component in cellular protection from oxidative stress. Taken together, these considerations raise the possibility that ROS plays a role in the mechanism by which trophic factor deprivation leads to neuronal apoptosis. Moreover, it is even conceivable that ROS plays a role in signaling re-entry into the cell cycle (Ferrari et al., 1995).

Despite these considerations, there are several observations 
A
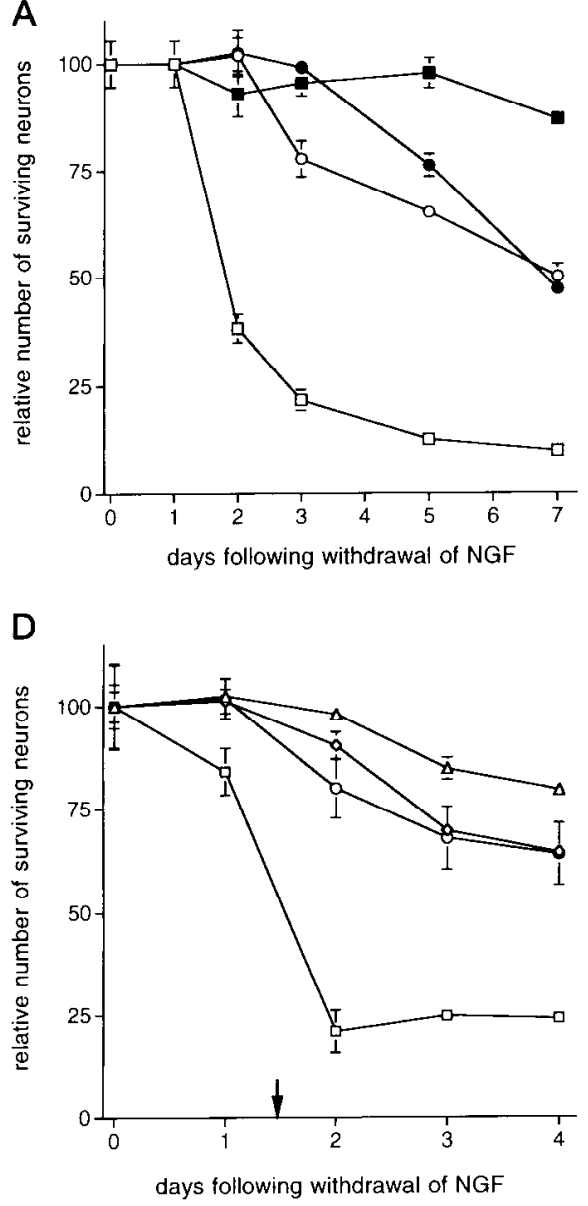

B
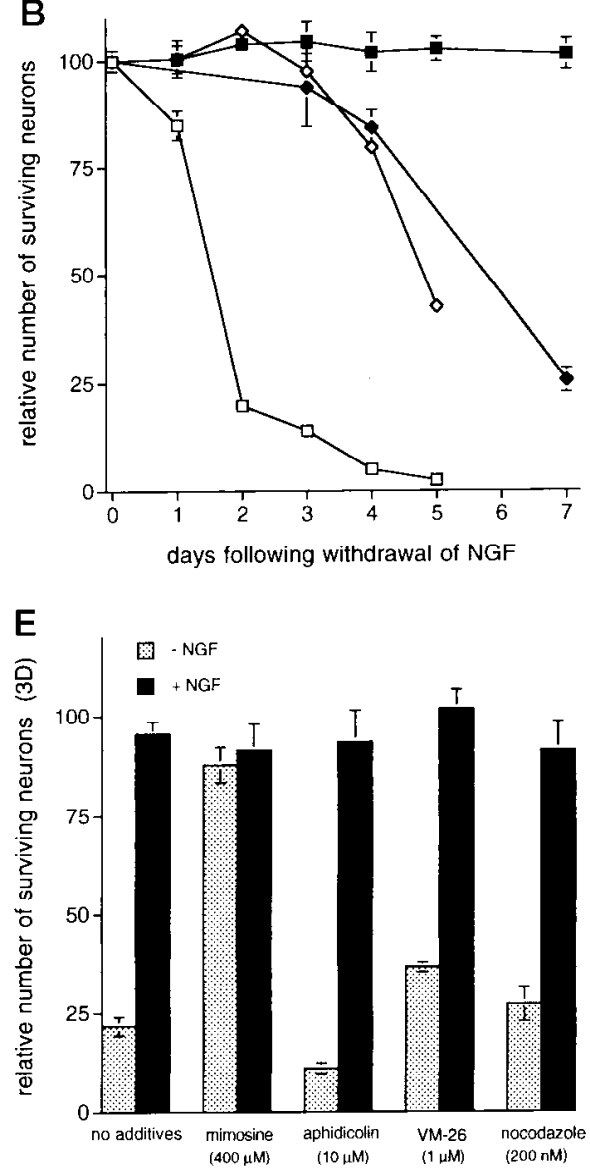

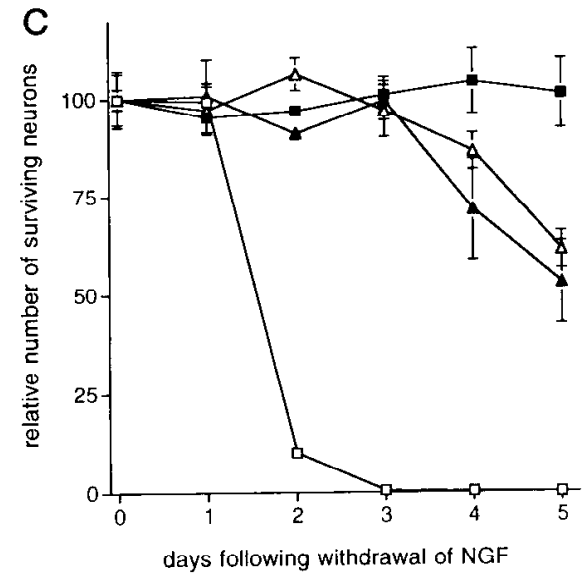

days following withdrawal of NGF

Figure 9. Gl blockers suppress the death of primary sympathetic neurons after removal of NGF, whereas S-, G2-, and M-phase blockers do not. Neurons were cultured in the presence of NGF for $6 \mathrm{~d}$ before its withdrawal (for only $3 \mathrm{~d}$ in the CPX experiment; see Materials and Methods). Cultures were not pretreated with agents before NGF withdrawal. $A$, Effects of mimosine on survival of sympathetic neurons after removal of NGF: ( $\square$ ) no additives; ( $\square$ ) NGF: (O) $400 \mu \mathrm{M}$ mimosine; (O) 400 $\mu \mathrm{M}$ mimosine + NGF, $B$, Effects of deferoxamine on survival of sympathetic neurons after removal of NGF: ( $\square$ ) no additives; $(\square)$ NGF; $(\diamond) 1 \mathrm{~mm}$ deferoxamine; $(\bullet) 1 \mathrm{~mm}$ deferoxamine + NGF. $C$, Effects of CPX on survival of sympathetic neurons after removal

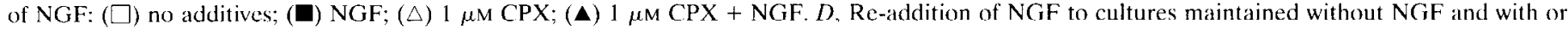
without Gl/S blockers for $36 \mathrm{hr}$. Neurons were deprived of NGF as described above. Thirty-six hours (arrow) after NGF withdrawal with or without exposure to the G1/S blockers, the cultures were washed once and NGF was added back into the medium lacking the blockers. Neurons were deprived of NGF and replaced with medium containing $(\square)$ no additives, $(\bigcirc) 400 \mu \mathrm{m}$ mimosine, $(\diamond) 1 \mathrm{~mm}$ deferoxamine, or $(\triangle) 1.5 \mu \mathrm{M}$ CPX before re-addition of NGF. E, S-, G2-, and M-phase blockers (mimosine, aphidicolin, VM-26, nocodazole) fail to prevent the death of primary sympathetic neurons after removal of NGF ( $3 \mathrm{~d}$ after NGF withdrawal). Meshed bars indicate no NGF; filled bars indicate added NGF. Cell survival data are expressed relative to the number present after removal of NGF. All data are the mean \pm SEM of three samples.

that tend to disfavor the likelihood that mimosine and deferoxamine protect neurons from growth factor withdrawal by suppressing oxidative stress. First, antioxidants such as vitamin E, butylated hydroxyanisole, and vitamin $\mathrm{C}$, which prevent death induced by oxidative stress in a variety of cell systems (Sies, 1993; Greenspan and Aruoma, 1994), fail to rescue PC12 cells from trophic factor withdrawal (Ferrari et al., 1995). Particularly germane is the finding that SODI depletion in PC12 cells leads to their rapid apoptotic death, presumably via an oxidative stress mechanism (Troy and Shelanski, 1994). In this case, low concentrations of vitamin E effectively prevent death, whereas long-term NGF exposure does not. Furthermore, although mimosine and deferoxamine prevent the death of $\mathrm{PCl} 2$ cells in the SOD1 depletion model, they do so at concentrations that are orders of magnitude lower than those required to block apoptosis and DNA synthesis in the presently studied trophic factor withdrawal paradigm (Troy et al., 1996). These considerations, therefore, indicate that PC12 cell death caused by oxidative stress and by trophic factor removal proceed, at least initially, by separate pathways. The necessary role for oxidative stress in programmed cell death is questioned further by the finding that in certain model systems, including one involving trophic factor deprivation, generation of ROS does not seem to be required for apoptotic death (Jacobson and Raff, 1995).

In summary, we have shown that mimosine, deferoxamine, CPX, and a permeant cAMP analog show good correlation between the concentrations necessary to block DNA synthesis and those necessary to suppress apoptotic death of neuronal cells caused by withdrawal of trophic support. This supports the hypothesis that neuronal cells die when deprived of trophic factors because they attempt abortive cell cycle progression, and it draws particular attention to a critical checkpoint at or before the G1/S border. Although apparently less likely, an alternative is that these agents protect trophic factor-deprived cells from death by their 

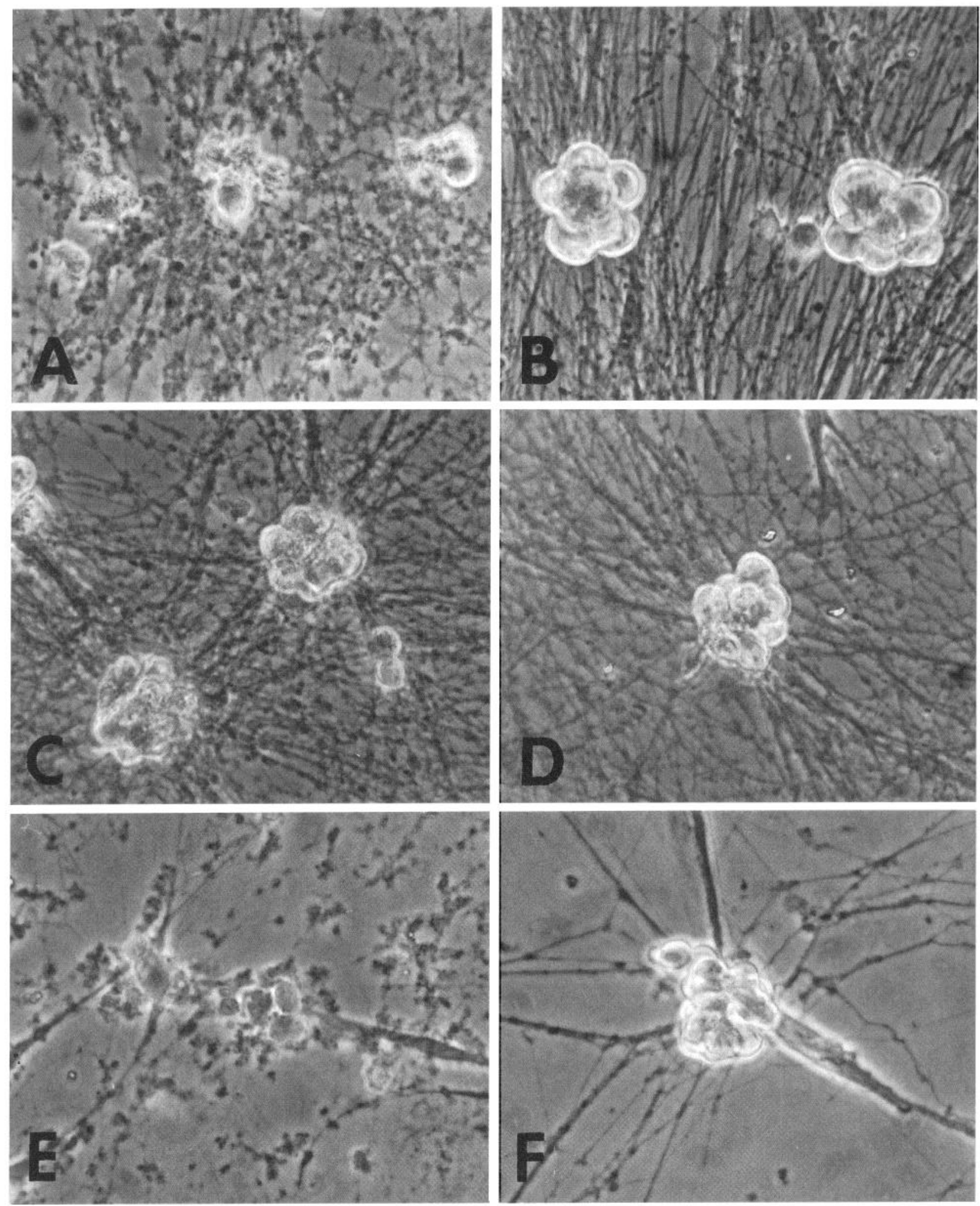

Figure 10. Phase-contrast micrographs of cultured primary sympathetic neurons maintained for $3 \mathrm{~d}$ after withdrawal of NGF and addition of $(A)$ no additives, $(B) 100 \mathrm{ng} / \mathrm{ml} \mathrm{NGF},(C) 400 \mu \mathrm{M}$ mimosine, $(D) 1 \mathrm{~mm}$ deferoxamine, $(E)$ no additives (control for CPX experiment), or $(F) 2 \mu \mathrm{M} C P X$ olamine. Magnification, $375 \times$. 
capacities to chelate iron and thereby prevent formation of ROS. In either case, mimosine, deferoxamine, and $\mathrm{CPX}$ represent promising classes of agents that might be developed further to prevent neuronal death in a clinical context and to dissect the mechanisms by which trophic factors regulate neuronal survival.

\section{REFERENCES}

Adams RLP, Lindsay JG (1967) Hydroxyurea: reversal of inhibition and use as a cell-synchronizing agent. J Biol Chem 242:1314-1317.

Batistatou A, Greene LA (1991) Aurintricarboxylic acid rescues PC12 cells and sympathetic neurons from cell death caused by nerve growth factor deprivation: correlation with suppression of endonuclease activity. J Cell Biol 115:461-471.

Batistatou A, Greene LA (1993) Internucleosomal DNA cleavage and neuronal cell survival/death. J Cell Biol 122:523-532.

Batistatou A, Merry DE, Korsmeyer SJ, Greene LA (1993) Bci-2 affects survival but not neuronal differentiation of PC12 cells. J Neurosci $13: 4433-4428$

Boehme SA, Lenardo MJ (1993) Propriocidal apoptosis of mature T lymphocytes occurs at $S$ phase of the cell cycle. Eur $\mathbf{J}$ Immunol 23:1552-1560.

Boniece IR, Wagner JA (1993) Growth factors protect PCl2 cells against ischemia by a mechanism that is independent of PKA, $\mathrm{PKC}$, and protein synthesis. J Neurosci 13:4220-4228.

Boynton AL, Whitfield JF (1983) The role of cyclic AMP in cell proliferation: a critical assessment of the evidence. Adv Cyclic Nucleotide Res 15:193-294.

Brodie C, Siriwardana G, Lucas J, Schleicher R, Terada N, Szepesi A, Gelfand E, Seligman P (1993) Neuroblastoma sensitivity to growth inhibition to desferrioxamine: evidence for a block in Gl phase of the cell cycle. Cancer Res 53:3968-3975.

Brooks SF, Gibson A, Rubin LL (1993) Apoptosis induced by NGF withdrawal from differentiated $\mathrm{PC} 12$ eclls involves activation of $\mathrm{p} 34^{\text {cde } 2}$ kinase (Abstr). Soc Neurosci 19:885A.

Carbonaro-Hall D, Williams R, Wu L, Warburton D, Zeichner-David M, Tolo V, Hall F (1993) G1 expression and multistage dynamics of cyclin $A$ in human osteosarcoma cells. Oncogene 8:1649-1659.

Chen M, Beck WT (1993) Teniposide-resistant CEM cells, which express mutant DNA topoisomerase IIa, when treated with non-complexstabilizing inhibitors of the enzyme, display no cross-resistance and reveal functions of the mutant enzyme. Cancer Res 53:5946-5953.

Colombel M, Olsson CA, Ng PY, Buttyan R (1992) Hormone-regulated apoptosis results from recntry of differentiated prostate cells onto a defective cell cycle. Cancer Res 52:4313-4319.

Deckwerth TL, Johnson Jr EM (1993) Temporal analysis of events associated with programmed cell death (apoptosis) of sympathetic neurons deprived of nerve growth factor. J Cell Biol 123:1207-1222.

Edwards SN, Tolkovsky AM (1994) Characterization of apoptosis in cultured rat sympathetic neurons after nerve growth factor withdrawal. J Cell Biol 124:537-546.

Edwards SN, Buckmaster AE, Tolkovsky AM (1991) The death programme in cultured sympathetic neurones can be suppressed at the post-translational level by nerve growth factor, cyclic AMP and depolarization. J Neurochem 57:2140-2143.

Evan GE, Wyllie AH, Gilbert CS, Littlewood TD, Land H, Brooks M, Waters CM, Penn LZ, Hancock DC (1992) Induction of apoptosis in fibroblasts by c-Myc protein. Cell 69:119-128.

Feldman ST, Schonthal A (1994) Negative regulation of histone H1 kinase expression by mimosine, a plant amino acid. Cancer Res 54:494-498.

Ferrari G, Greene LA (1994) Proliferative inhibition by dominantnegative Ras rescues naive and ncuronally-differentiated $\mathrm{PC} 12$ cells from apoptotic death. EMBO J 13:5922-5928.

Ferrari G, Yan CYI, Greene LA (1995) $N$-acetylcysteine (D- and L-stereoisomers) prevents apoptotic death of neuronal cells. J Neurosci 15:2857-2866.

Freeman RF, Estus S, Johnson Jr EM (1994) Analysis of cell-related gene expression in postmitotic neurons: selective induction of Cyclin DI during programmed cell death. Neuron 12:343-355.

Ganeshaguru K, Hoffbrand AV, Grady RW, Cerami A (1980) Effects of various iron chelating agents on DNA synthesis in human cells. Biochem Pharmacol 29:1275-1279.
Garcia I, Martinou I, Tsujimoto Y, Martinou JC (1992) Prevention of programmed cell death of sympathetic neurons by the bel-2 protooncogene. Science 258:302-304.

Grecne LA (1978) Nerve growth factor prevents the death and stimulates neuronal differentiation of clonal $\mathrm{PC} 12$ pheochromocytoma cells in serum-free medium. J Cell Biol 78:747-755.

Greene LA, Tischler AS (1976) Establishment of a noradrenergic clonal line of rat adrenal pheochromocytoma cells which respond to nerve growth factor. Proc Natl Acad Sci USA 73:2424-2428.

Greene LA, Tischler AS (1982) PC12 pheochromocytoma cells in neurobiological research. Adv Cell Neurobiol 3:373-414.

Greene LA, Farinelli SE, Yan I, Ferrari G (1995a) On the mechanisms by which neurotrophic factors regulate neuronal survival and cell death. In: Death in the nervous system (Ibanez CF, Fuxe K, Hokfelt T, Jornvall $\mathrm{H}$, Olsen L, Ottosen D, eds). New York: Pergamon, in press.

Greene LA, Ferrari G, Farinelli SE (1995b) Regulation of neuronal death by neurotrophic factors: a cell cycle-related mechanism? Perspect Dev Biol, in press.

Greene LA, Sobeih MM, Teng KK (1991) Methodologies for the culture and experimental use of the PC12 rat pheochromocytoma cell line. In: Culturing nerve cells (Banker G, Goslin K, eds), pp 207-226. Cambridge: MIT.

Greenlund LJS, Deckwerth TL, Johnson Jr EM (1995) Superoxide dismutase delays neuronal apoptosis: a role for reactive oxygen species in programmed neuronal death. Neuron 14:303-315.

Greenspan HC, Aruoma OI (1994) Oxidative stress and apoptosis in HIV infection: a role for plant-derived metabolites with synergistic antioxidant activity. Immunol Today 15:209-213.

Guroff G (1985) PC12 cells as a model of neuronal differentiation. In: Cell culture in neuroscience (Bottenstein JE. Sato G, eds), pp 245-266. New York: Plenum.

Hanauske-Abel HM, Park MH, Hanauske AR, Popowicz AM, Lalande M, Folk JE (1994) Inhibition of the G1-S transition of the cell cycle by inhibitors of deoxyhypusine hydroxylation. Biochim Biophys Acta 1221:115-124.

Hashiguchi H, Takahashi $H$ (1977) Inhibition of two copper-containing enzymes, tyrosine and dopamine $\beta$-hydroxylase, by 1 -mimosine. Mol Pharmacol 13:362-367.

Heintz N (1993) Cell death and the cell cycle: a relationship between transformation and neurodegeneration? Trends Biochem Sci 18:157-159.

Hoffman BD, Hanauske-Abel HM, Flint A, Lalande M (1991) A new class of reversible cell cycle inhibitors. Cytometry 12:26-32.

Ikegami S, Taguchi T, Ohashi M, Oguro M, Nagano H, Mano Y (1978) Aphidicolin prevents mitotic division by interfering with the activity of DNA polymerase- $\alpha$. Nature 275:458-460.

Jackson RC (1978) The regulation of thymidylate biosynthesis in Novikoff hepatoma cells and the effects of amethopterin, 5-fluorodeoxyuridine, and 3-deazauridine. J Biol Chem 253:7440-7446.

Jacobson MD, Raff MC (1995) Programmed cell death and Bcl-2 protection in very low oxygen. Nature 374:814-816.

Jue SG, GW Dawson, Brogden RN (1985) Ciclopirox olamine 1\% cream: a preliminary review of its antimicrobial activity and therapeutic use. Drugs 29:330-341.

Kane D.I, Sarafian TA, Anton R, Hahn H, Gralla EB, Valentine JS, Ord T, Bredesen DE (1993) Bcl-2 inhibition of neural death: decreased generation of reactive oxygen species. Science 262:1274-1277.

Kato J, Matsuoka M, Polyak K, Massague J, Sherr CJ (1994) Cyclic AMP-induced $G 1$ phase arrest mediated by an inhibitor ( $227^{\mathrm{Kipl}}$ ) of cyclin-dependent kinase 4 activation. Cell 79:487-496.

Kontoghiorghes GJ, Evans RW (1985) Site specificity of iron removal from transferrin by $\alpha$-ketohydroxypyridine chelators. FEBS Lett 189:141-144.

Lalande $M$ (1990) A reversible arrest point in the late $G 1$ phase of the mammalian cell cycle. Exp Cell Res 186:332-339.

Lee VM, Shelanski ML, Greene LA (1980) Characterization of antisera raised against cultured rat sympathetic neurons. Neuroscience 5:2239-2245

Lenardo MJ (1991) Interleukin-2 programs mouse Ab T lymphocytes for apoptosis. Nature 353:858-861.

Mah SP, Zhong LT, Liu Y, Roghani A, Edwards RH, Bredesen DE (1993) The protooncogene bcl-2 inhibits apoptosis in PC12 cells. J Neurochem 60:1183-1186. 
Martin DP, Ito AI, Horigome K, Lampe PA, Johnson Jr EM (1992) Biochemical characterization of programmed cell death in NGFdeprived sympathetic neurons. J Neurobiol 23:1205-1220.

Martin DP, Schmidt RE, DiStefano PS, Lowry OH, Carter JG, Johnson Jr EM (1988) Inhibitors of protein synthesis and RNA synthesis prevent neuronal death caused by nerve growth factor deprivation. J Cell Biol 106:829-844

Mesner PW. Winters TR, Green SH (1992) Nerve growth factorwithdrawal induced cell death in neuronal PCI2 cells resembles that in svmpathetic neurons. J Cell Biol 119:1669-1680.

Pan Z, Percz-Polo R (1993) Role of nerve growth factor in oxidant homeostasis: glutathione metabolism. J Neurochem 61:1713-1721.

Park MH, Wolff EC, Folk JE (1993) Is hypusine essential for eukaryotic cell proliferation? Trends Biochem Sci 18:475-479.

Pittman RN, Wang S, Di Benedetto AJ, Mills J (1993) A system for characterizing cellular and molecular events in programmed neuronal cell death. J Neurosci 13:3669-3680.

Ratan RR. Murphy TH, Baraban JM (199/a) Macromolecular synthesis inhibitors prevent oxidative stress-induced apoptosis in embryonic cortical neurons by shunting cysteine from protcin synthesis to glutathione. J Neurosci 14:4385-4392.

Ratan RR, Murphy TH, Baraban JM (1994b) Oxidative stress induces apoptosis in embryonic cortical neurons. J Neurochem 62:376-379.

Robbins E, Pederson I' (1970) Irom: its intracellular localization and possible role in cell division. Proc Natl Acad Sci USA 66:1244-1251.

Roberge M, Th'ng J, Hamaguchi J, Bradbury EM (1990) The topoisomerase inhibitor VM-26 induces marked changes in histone $\mathrm{H} 1$ kinase activity, histones $\mathrm{H} 1$ and $\mathrm{H} 3$ phosphorylation, and chromosome condensation in $\mathrm{I}_{2}$ phase and mitotic BHK cells. $J$ Cell Biol 111:1753-1762.

Rubin LL, Philpott KL, Brooks SF (1993) The cell cycle and cell death. Curr Biol 3:391-394.

Rudkin BB, Lazarovici P, Levi B, Abe Y, Fujita K, Guroff G (1989) Cell cycle-specific action of nerve growth factor in PC12 cells: differentiation without proliferation. EMBO J 8:3319-3325.

Rukenstein A, Rydel RE, Greene LA (1991) Multiple agents rescue PC 12 colls from scrum-free cell death by translation- and transcriptionindependent mechanisms. J Neurosci 1 1:2552-2563.

Rydel RE, Greene LA (1988) cAMP analogs promote survival and neurite outgrowth in cultures of rat sympathetic and sensory neurons independently of nerve growth factor. Proc Natl Acad Sci USA 85:1257-1261.

Schiff PB, Fant J, Horwitz SB (1979) Promotion of microtubule assembly in vitro by taxol. Nature 277:665-667.

Shi L, Nishioka WK, Th'ng J, Bradbury EM, Litchfield DW, Greenberg AH (1994) Premature p34 coc activation required for apoptosis. Science 263: 1143-1145

Sies H (1993) Strategies of antioxidant defense. Eur J Biochem 215:213-219.

Soto AM, Sonnenschein C (1985) The role of estrogens on the proliferation of human breast tumor cells (MCF-7). J Steroid Biochem 23:87-94.

Terada N, Lucas JJ, Gelfand EW (1991) Differential regulation of the tumor suppressor molecules, retinoblastoma susceptibility gene product (Rb) and p53, during cell cycle progression of normal human $T$ cells. J Immunol 147:698-704.

Terada N, Or R, Szepesi A, I ucas JJ, Gelfand EW (1993) Definition of the roles for iron and essential fatty acids in cell cycle progression of normal human T lymphocytes. Exp Cell Res 204:260-267.

Tischler AS, Riseberg JC, Hardenbrook MA, Cherington V (1993) Nerve growth factor is a potent inducer of proliferation and neuronal differentiation for adult rat chromaffin cells in vitro. J Neurosci $13: 153.3-1542$.

Troy CM, Shelanski ML (1994) Downregulation of copper/zinc superoxide dismutase causes apoptotic death in PCI2 neuronal cells. Proc Natl Acad Sci USA 91:6384-6387.

Troy CM, Derossi D, Prochiantz A, Greene LA, Shelanski ML. (1996) Downregulation of $\mathrm{Cu} / \mathrm{Zn}$ superoxide dismutase leads to cell death via the nitric oxide-peroxynitrite pathway. J Neurosci 16:253-261.

Wilson L, Jordan MA (1994) Pharmacological probes of microtubule function. In: Microtubules (Hyams JS, Lloyd CW, eds), pp 59-83. New York: Wiley.

Yonish-Rouach E, Grunwald D, Wilder S, Kimchi A, May E, Lawrence JJ, May P, Oren M (1993) P53-mediated cell death: relationship to cell cycle control. Mol Cell Biol 13:1415-1423.

Yonish-Rouach E, Resnitzky D, Lotem J, Sachs L, Kimchi A, Oren M (1991) Wild-type p53 apoptosis of myeloid leukatemic cells that is inhibited by interleukin-6. Nature 352:345-347. 